\title{
Penerapan Pembelajaran Model Kooperatif Tipe Think-Pair-Share Dalam Materi Usaha Dan Energi Ditinjau Dari Gender Siswa Kelas Xi Ipa Sma Negeri 1 Sungai Ambawang
}

\author{
Ira Nofita Sari ${ }^{1)}$, Masriana ${ }^{2)}$ \\ ${ }^{1)}$ Prodi Pendidikan Fisika IKIP PGRI Pontianak \\ E-mail:iranofitasari87@gmail.com \\ 2) Prodi Pendidikan Fisika IKIP-PGRI Pontianak \\ E-mail:masriana@yahoo.com
}

\begin{abstract}
Abstrak. Penelitian ini bertujuan untuk mengetahui penerapan pembelajaran model kooperatif tipe think-pair-share dalam materi usaha dan energi ditinjau dari gender siswa kelas XI IPA SMA Negeri 1 Sungai Ambawang. Adapun variabel dalam penelitian ini adalah hasil belajar siswa laki-laki dan hasil belajar siswa perempuan. Metode yang digunakan dalam peneltian ini adalah metode eksperimen dan bentuk penelitian eksperimen yang digunakan adalah Pre-Eksperimental Designs dengan rancangan penelitian The One-Shot Case Study.Sampel yang digunakan ialah kelas XI IPA 1 yang diambil secara purposive sampling.. Teknik pengumpul data yang digunakan dalam penelitian ini adalah teknik pengukuran dengan alat pengumpul data berupa tes yang berbentuk essay. Berdasarkan hasil analisis data penelitian diperoleh kesimpulan: (1) Rata-rata hasil belajar siswa laki-laki yang diajarkan model pembelajaran kooperatif tipe think-pair-share dalam materi usaha dan energi siswa kelas XI IPA SMA Negeri 1 Sungai Ambawang mencapai KKM (72) dengan nilai signifikansi lebih besar dari taraf signifikansi $5 \%(0,715>0,05)$. (2) Rata-rata hasil belajar siswa perempuan yang diajarkan model pembelajaran kooperatif tipe think-pair-share dalam materi usaha dan energi siswa kelas XI IPA SMA Negeri 1 Sungai Ambawang mencapai KKM (72) dengan nilai signifikansi lebih besar dari taraf signifikansi 5\% $(0,185>0,05)$. (3) Terdapat perbedaan antara rata-rata hasil belajar siswa laki-laki dengan rata-rata hasil belajar siswa perempuan yang diajarkan model pembelajaran kooperatif tipe Think-Pair-Share dalam materi usaha dan energi siswa kelas XI IPA SMA Negeri 1 Sungai Ambawang dengan nilai signifikansi lebih besar dari taraf signifikansi 5\% $(0,101>0,05)$.
\end{abstract}

Kata Kunci: model kooperatif, tipe think-pair-share, usaha dan energi, gender

\section{PENDAHULUAN}

Mata pelajaran fisika di SMA dikembangkan dengan mengacu pada pengembangan fisika yang ditujukan untuk mendidik siswa agar mampu mengembangkan pengetahuan serta memiliki keterampilan dalam ilmu dan teknologi. Pembelajaran fisika di sekolah merupakan pembelajaran secara konseptual yang menyediakan pengalaman belajar agar siswa dapat memahami materi yang disampaikan dengan memahami konsep dan prinsip serta penerapannya dalam kehidupan sehari-hari.

Konsep fisika atau ilmu fisika akan bernilai guna bagi manusia kalau ilmu fisika sudah diwujudkan dalam teknologi. Berbagai teknologi yang ada dapat digunakan sebagai contoh atau media dalam proses belajar mengajar. Berbagai peralatan yang berkembang saat ini karena adanya kemajuan teknologi berdasar pada ilmu fisika.Mulai dari peralatan dapur sampai peralatan industri menggunakan prinsip kerja yang ada di ilmu fisika. Penguasaan ilmu fisika dapat dilihat dari hasil belajar yang di peroleh siswa di sekolah.

Hasil belajar dapat tercapai apabila guru dalam menyampaikan pelajaran dengan tidak menjadikan siswa hanya sebagai obyek belajar, tetapi siswa dijadikan sebagai subyek, sehingga siswa bisa terlibat langsung dalam proses pembelajaran. Selain itu juga, guru tidak hanya menggunakan model pembelajaran yang monoton, tetapi guru harus bisa mengembangkan model pembelajaran yang bervariasi dan menyenangkan agar siswa 


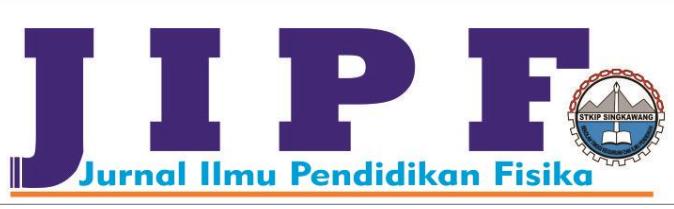

senang dalam mengikuti pelajaran, sehingga tercapai hasil belajar siswa yang baik.

Berdasarkan hasil wawancara dengan guru mata pelajaran fisika di SMA Negeri 1 Sungai Ambawang pada tanggal 24 Februari 2014, menyatakan bahwa dalam proses pembelajaran fisika siswa belum terlibat secara aktif, siswa belum dapat mengungkapkan pendapatnya dengan konsep yang dipelajari dan siswa kurang dapat membuat kesimpulan dari konsep. Kegiatan yang demikian menyebabkan rendahnya hasil belajar siswa.

Rendahnya hasil belajar siswa dapat dilihat dari rata-rata ulangan harian siswa kelas XI IPA SMA Negeri 1 Sungai Ambawang tahun ajaran 2013/2014 dengan nilai terendah yaitu pada pokok bahasan Usaha dan energi yaitu 51,29. Materi usaha dan energi merupakan materi yangdianggap sulit oleh siswa, karena siswa sebagaian besar kesulitan apabila diberikan soal yang bervariasi, terlebih lagi siswa nya yang mengerjakan secara individu.

Salah satu upaya yang harus dilakukan untuk mengatasinya yaitu dengan penggunaan model pembelajaran yang tepat. Model pembelajaran kooperatif merupakan model pengajaran yang melibatkan siswa untuk belajar dalam kelompokkelompok kecil yang memiliki tingkat kemampuan yang berbeda-beda. Setiap anggota saling bekerja sama dan membantu untuk memahami suatu bahan pembelajaran maupun menyelesaikan tugas kelompok. Kegiatan pembelajaran yang demikian menyebabkan peningkatanhasil belajar siswa.

Pembelajaran kooperatif memiliki beberapa tipe, salah satunya adalah pembelajaran kooperatif tipe think-pair-share atau berfikir-berpasangan-berbagi. Tipe ini dikembangkan pertama kali oleh Frank Lyman dan kolegannya di Universitas Maryland yang menyatakan bahwa think-pair-share merupakan suatu cara yang efektif untuk membuat variasi suasana pola diskusi kelas, membutuhkan pengaturan untuk mengendalikan kelas secara keseluruhan, dan prosedur yang digunakan dalam tipe ini dapat memberi siswa lebih banyak waktu berfikir untuk merespon dan saling membantu [1].

Pembelajaran kooperatif dengan tipe pembelajaran think-pair-share merupakan salah satu tipe pembelajar yang menuntut siswa untuk berperan aktif dalam pelaksanaan proses belajar mengajar. Siswa dituntut untuk berpikir kritis mulai
Jurnal Ilmu Pendidikan Fisika

Volum 1 Nomor 2 September 2016. Halaman 52-58 p-ISSN: 2477-5959 e-ISSN: 2477-8451

dari secara individu, kemudian secara berpasangan mendiskusikan apa yang telah dipikirkan, selanjutnya siswa dituntut untuk saling bekerja sama dengan teman sekelas secara keseluruhan mengenai apa yang telah mereka diskusikan dengan pasangannya.

Penerapan model pembelajaran kooperatif tipe think-pair-share diharapkan dapat melatih siswa untuk dapat saling membantu dengan yang lain, saling berdiskusi dan berargumentasi untuk mengasah pengetahuan yang mereka kuasai saat itu dan menutup kesenjangan dalam pemahaman masing-masing. Model ini juga dapat meningkatkan keterampilan berkomunikasi melalui pasangan dan mempersentasikan jawaban dari suatu pertanyaan yang diajukan oleh guru. Setiap siswa dituntut untuk terlibat langsung mencari alternatif jawaban dari suatu masalah pertanyaan yang diajukan oleh guru secara aktif dalam proses pembelajaran, sehingga dapat mengembangkan keterampilan tingkat tinggi dan meningkatkan ingatan siswa.

Salah satu faktor yang menarik dalam proses pembelajaran yang berpengaruh terhadap hasil belajar yaitu faktor gender atau jenis kelamin. Perbedaan gender dalam pendidikan dapat menyebabkan adanya perbedaan prestasi belajar. Ada beberapa argumentasi yang dapat digunakan untuk menjelaskan perbedaan prestasi belajar antara laki-laki dan perempuan, di antaranya adalah pernyataan "Perempuan dalam hal ini diposisikan sebagai individu yang memiliki prestasi yang lebih baik dari pada laki-laki, ketika perempuan diberikan kesempatan yang sama dengan laki-laki untuk mengembangkan kemampuannya di sektor publik maka perempuan berupaya untuk mencapai tingkat pendidikan setinggi mungkin" [2].

Perbedaan prestasi belajar laki-laki dan perempuan lebih disebabkan oleh tingkat intelegensi. Laki-laki lebih aktif daripada perempuan, akan tetapi keaktifan laki-laki ini kemudian menyebabkan laki-laki menjadi lebih sulit untuk diatur hal inilah yang menyebabkan laki-laki memiliki prestasi belajar yang lebih rendah daripada perempuan [2].

Beberapa penelitian yang memberikan hasil positif terhadap peningkatan hasil belajar siswa menggunakan model pembelajaran kooperatif tipe 


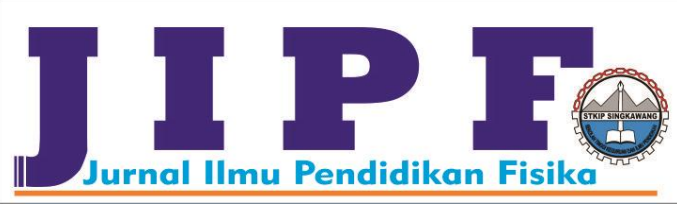

think-pair-share telah dilakukan antara lain, Soleha, mendapatkan bahwa pada siklus I nilai rata-rata hasil belajar siswa sebelum pembelajaran menggunakan model kooperatif tipe think-pairshare adalah 33,75 dan sesudah pembelajaran adalah 90,63\%. Pada siklus II nilai rata-rata hasil belajar siswa sebelum pembelajaran menggunakan model kooperatif tipe think-pair-share adalah 41,25 dan sesudah pembelajaran adalah $93,75 \%$. Saparia (2010), pada siswa kelas XI SMA Mujahidin Pontianak dikategorikan baik, ini berarti pembelajaran kooperatif tipe think-pair-share efektif ditinjau dari hasil belajar siswa yaitu presentase siswa yang mendapat nilai $\geq 63$ adalah $86,21 \%$ [3].

Berdasarkan uraian di atas peneliti tertarik untuk melakukan penelitian dengan judul Penerapan Pembelajaran Model Kooperatif mengetahui hasil belajar model pembelajaran kooperatiftipe thinkpair-share pada materi usaha dan energi yang ditinjau dari gender siswa di kelas XI IPA SMA Negeri 1 Sungai Ambawang, dengan tujuan untuk mengetahui 1) Rata-rata hasil belajar siswa lakilaki yang diajarkan model kooperatif tipe thinkpair-share dalam materi usaha dan energi siswa kelas XI IPA SMA Negeri 1 Sungai Ambawang; 2) Rata-rata hasil belajar siswa perempuan yang diajarkan model kooperatif tipe think-pair-share dalam materi usaha dan energi siswa kelas XI IPA SMA Negeri 1 Sungai Ambawang; 3) Perbedaan antara rata-rata hasil belajar siswa laki-laki dan siswa perempuan setelah diajarkan model pembelajaran kooperatif tipe think-pair-share dalam materi usaha dan energi siswa kelas XI IPA SMA Negeri 1 Sungai Ambawang.

\section{Metode}

Metode penelitian yang digunakan dalam penelitian ini adalah metode eksperimen. Metode penelitian eksperimen dapat diartikan sebagai metode penelitian yang digunakan untuk mencari pengaruh perlakuan tertentu terhadap yang lain dalam kondisi yang dikendalikan [4]. Metode eksperimen ini digunakan karena peneliti hanya memberikan perlakuan kemudian mengukur hasil dari perlakuan tersebut.

Populasi adalah wilayah generalisasi yan terdiri dari objek atau subjek yang mempunyai kuantitas
Jurnal Ilmu Pendidikan Fisika

Volum 1 Nomor 2 September 2016. Halaman 52-58 p-ISSN: 2477-5959 e-ISSN: 2477-8451

dan karakteristik tertentu yang ditetapkan oleh peneliti untuk dipelajari dan kemudian ditarik kesimpulan [4]. Adapun yang menjadi populasi dalam penelitian ini adalah siswa kelas XI IPA SMA Negeri 1 Sungan Ambawang yang terdiri dari XI IPA 1 dan XI IPA 2. Anggota sampel yang diambil dalam penelitian ini adalah kelas XI IPA 1 sebagai kelompok eksperimen.

Teknik pengumpulan data yang digunakan dalam penelitian ini adalah teknik pengukuran. Pengukuran yang dimaksud dalam penelitian ini adalah pemberian tes untuk mengetahui hasil belajar siswa pada materi usaha dan energi, dengan memberikan posttest berbentuk uraian tes, setiap butir soal diberikan skor sesuai dengan tabel penskoran dan kunci jawaban.

Teknik analisis data dalam penelitian ini adalah penelitian kuantitatif menggunakan statistik. Statistik yang digunakan untuk menganalisis data dengan cara mendeskripsikan atau menggambarkan data yang telah terkumpul sebagaimana adanya tanpa bermaksud membuat kesimpulan yang berlaku umum atau generalisasi [4].

\section{HASIL DAN PEMBAHASAN}

Penelitian ini bertujuan untuk mengetahui penerapan pembelajaran model kooperatif tipe think-pair-share dalam materi usaha dan energi ditinjau dari gender siswa kelas XI IPA SMA Negeri 1 Sungai Ambawang, serta untuk mengetahui 1) Rata-rata hasil belajar siswa lakilaki yang diajarkan model kooperatif tipe ThinkPair-Sharedalam materi usaha dan energi siswa kelas XI IPA SMA Negeri 1 Sungai Ambawang; 2) Rata-rata hasil belajar siswa perempuan yang diajarkan model kooperatif tipe Think-PairSharedalam materi usaha dan energi siswa kelas XI IPA SMA Negeri 1 Sungai Ambawang; 3) Perbedaan antara rata-rata hasil belajar siswa lakilaki dan siswa perempuan setelah diajarkan model pembelajaran kooperatif tipe Think-Pair-Share dalam materi usaha dan energi siswa kelas XI IPA SMA Negeri 1 Sungai Ambawang.

Penelitian ini dilaksanakan pada tanggal 16 - 23 Oktober 2014 di kelas XI IPA 1 SMA Negeri 1 Sungai Ambawang pada tahun ajaran 2014/2015 yang berjumlah 28 orang siswa. Setelah melakukan proses belajar mengajar dengan menggunakan 


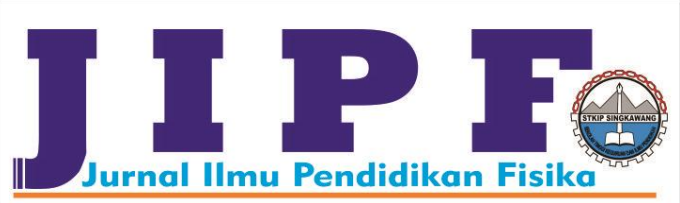

model pembelajaran kooperatif Tipe Think-PairShare, dilakukan post-test untuk melihat hasil belajar siswa kelas XI IPA 1 SMA Negeri 1 Sungai Ambawang. Adapun data post-test siswa laki-laki dapat dilihat pada Tabel 1 .

TABEL 1

DisTRIBUSI HASIL BELAJAR SISWA LAKI-LAKI SETELAH PEMBELAJARAN MODEL KOOPERATIF TIPE THINK-PAIR-SHARE

\begin{tabular}{ccc}
\hline No & Kode Siswa & Nilai Post-test \\
\hline 1 & A1 & 53,57 \\
2 & A2 & 66,07 \\
3 & A3 & 66,07 \\
4 & A4 & 94,64 \\
5 & A5 & 96,43 \\
\hline \multicolumn{3}{c}{ Rata-rata } \\
\end{tabular}

Berdasarkan data pada Tabel 1 diperoleh nilai rata-rata post-test siswa laki-laki ialah 75,36 hal tersebut menjawab sub masalah yang pertama mengenai rata-rata hasil belajar siswa laki-laki yang mencapai KKM dan nilai standar deviasinya ialah 19,12. Adapun data post-test siswa laki-laki dapat dilihat pada Tabel 2 .

\section{TABEL 2}

Distribusi HASIL BELAJAR SiSWA PEREMPUAN SETELAH PEMBELAJARAN MODEL KOOPERATIF TIPE THINK-PAIR-SHARE

\begin{tabular}{ccc}
\hline No & KodeSiswa & NilaiPost-Test \\
\hline 1 & B1 & 55,36 \\
2 & B2 & 57,14 \\
3 & B3 & 58,93 \\
4 & B4 & 64,29 \\
5 & B5 & 67,86 \\
6 & B6 & 71,43 \\
7 & B7 & 75,00 \\
8 & B8 & 78,57 \\
9 & B9 & 80,36 \\
10 & B10 & 82,14 \\
11 & B11 & 83,93 \\
12 & B12 & 85,71 \\
13 & B13 & 87,50 \\
14 & B14 & 89,29 \\
15 & B15 & 91,07 \\
16 & B16 & 92,86 \\
\hline
\end{tabular}

Berdasarkan data pada Tabel 2 diperoleh nilai rata-rata post-test siswa perempuan ialah 76,34 hal tersebut menjawab sub masalah yang kedua mengenai rata-rata hasil belajar siswa perempuan yang mencapai KKM dan nilai standar deviasinya ialah 12,48 .
Jurnal Ilmu Pendidikan Fisika

Volum 1 Nomor 2 September 2016. Halaman 52-58 p-ISSN: 2477-5959 e-ISSN: 2477-8451

Pengujian normalitas data dilakukan dengan bantuan SPSS versi 16. Hasil uji normalitas siswa laki-laki dan siswa perempuan dapat dilihat pada Tabel 3.

TABEL 3

UJI NORMALITAS SISWA LAKI-LAKI DAN SISWA PEREMPUAN

\begin{tabular}{cccc}
\hline \multicolumn{4}{c}{ Kolmogorov-Smirnov $^{\text {a }}$} \\
\hline Gender & Statistic & Df & Sig. \\
\hline Laki-laki & .286 & 5 & .200 \\
Perempuan & .234 & 5 & .200 \\
\hline
\end{tabular}

Berdasarkan Tabel 3 dapat dilihat nilai signifikansi siswa laki-laki dan siswa perempuan sama adalah 0,200 dengan kata lain nilai signifikansi $5 \%(0,200>0,05)$. Dapat disimpulkan bahwa data posttest pada siswa laki-laki dan siswa perempuan berdistribusi normal. Kedua data siswa laki-laki dan siswa perempuan berdistribusi normal, maka untuk uji hipotesis yang digunakan adalah uji t satu sampel (One Sample Test).

Pengujian hipotesis pertama dilakukan dengan uji-t satu sampel dengan bantuan SPSS versi 16. Hasil uji hipotesis pertama dapat dilihat pada Tabel 4.

TABEL 4

HASIL UJI-T SATU SAMPEL

\begin{tabular}{ccccccc}
\hline \multicolumn{1}{c}{ Test Value $=72$} \\
\hline Gender & t & Df & $\begin{array}{c}\text { Sig. } \\
(2- \\
\text { tailed })\end{array}$ & $\begin{array}{c}\text { Mean } \\
\text { Difference }\end{array}$ & $\begin{array}{c}\text { 95\% Confidence } \\
\text { Interval of the } \\
\text { Difference }\end{array}$ \\
\hline Laki-laki & .392 & 4 & .715 & 3.35600 & -20.3909 & 27.1029 \\
Perempuan & 1.391 & 15 & .185 & 4.34000 & -2.3115 & 10.9915 \\
\hline
\end{tabular}

Berdasarkan perhitungan Tabel 4 dapat dilihat bahwa nilai signifikansi perhitungan siswa laki-laki adalah sebesar 0,715. Sehingga nilai signifikansi perhitungan $(0,715)$ lebih besar dari taraf signifikansi $5 \%(0,715>0,05)$, maka disimpulkan bahwa hipotesis nol $\left(\mathrm{H}_{0}\right)$ diterima. Dapat dikatakan bahwa hasil belajar siswa laki-laki yang diajarkan model kooperatif tipe think-pair-sharemencapai KKM (72).

Pengujian hipotesis kedua dilakukan dengan ujit satu sampel dengan bantuan SPSS versi 16. 


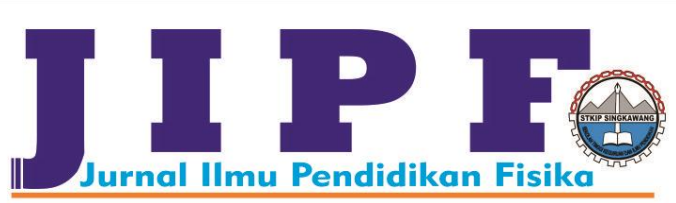

Berdasarkan Tabel 4 dapat dilihat bahwa nilai signifikansi perhitungan siswa perempuan adalah sebesar 0,185. Sehingga nilai signifikansi perhitungan $(0,185)$ lebih besar dari taraf signifikansi $5 \%(0,185>0,05)$, maka disimpulkan bahwa hipotesis nol (H0) diterima. Dapat dikatakan bahwa hasil belajar siswa perempuan yang diajarkan model kooperatif tipe think-pair-share mencapai KKM (72).

Pengujian hipotesis ketiga dilakukan dengan ujit dua sampel dengan bantuan SPSS versi 16. Hasil uji hipotesis ketiga dapat dilihat pada Tabel 5.

TABEL 5

HASIL UJI-T DUA SAMPEL

\begin{tabular}{ccc}
\hline \multirow{2}{*}{ Nilai } & \multicolumn{2}{c}{$\begin{array}{c}\text { Levene's Test for Equality of } \\
\text { Variances }\end{array}$} \\
\cline { 2 - 3 } & $\mathrm{F}$ & Sig. \\
\hline Equal variances assumed & 2.972 & .101
\end{tabular}

Berdasarkan Tabel 5 dapat dilihat bahwa nilai signifikansi perhitungan uji-t dua sampel adalah sebesar 0,101. Sehingg nilai signifikansi perhitungan $(0,101)$ lebih besar dari taraf signifikansi 5\% (0,101 >0,05, maka disimpulkan bahwa hipotesis nol (H0) diterima. Dapat dikatakan bahwa ada perbedaan antara hasil belajar siswa laki-laki dan siswa perempuan yang diajarkan model kooperatif tipe Think-Pair-Sharedalam materi usaha dan energi. Perbedaan rata-rata hasil belajar siswa laki-laki dan perempuan dapat dilihat pada Gambar 1.

Perbedaan nilai rata-rata hasil belajar siswa ini dikarenakan pada saat pembelajaran berlangsung siswa laki-laki cenderung pasif, sedangkan siswa perempuan tampak lebih aktif dan tidak malu untuk bertanya dan mengeluarkan pendapat. Sifat lakilaki dan perempuan memiliki respon yang berbeda terhadap hal-hal yang dipelajari [5]. Sifat tersebut misalnya rajin dan ketekunan dalam mempelajari pembelajaran. Hal tersebut dapat berpengaruh pada hasil belajar siswa.Perbedaan ini dapat juga terlihat dari setiap fase pembelajaran dengan model kooperatif tipe Think-Pair-Share.
Jurnal Ilmu Pendidikan Fisika

Volum 1 Nomor 2 September 2016. Halaman 52-58 p-ISSN: 2477-5959 e-ISSN: 2477-8451

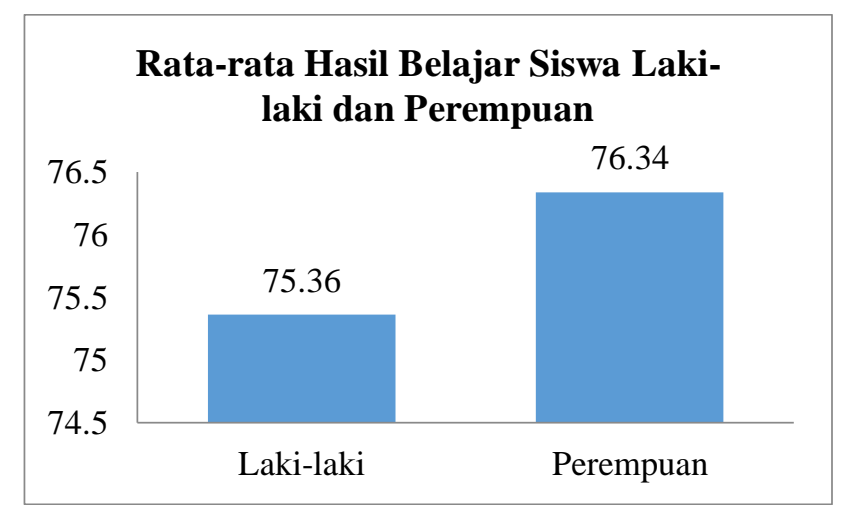

Gambar 1 Rata-rata Hasil Belajar Siswa Laki-Laki dan Perempuan

Pada fase I (Think), guru mengajukan pertanyaan atau masalah yang dikaitkan dengan pelajaran, dan meminta siswa menggunakan waktu beberapa menit untuk berpikir sendiri jawaban atau masalah. Dengan menuntut siswa untuk berfikir secara mandiri, maka pengetahuan akan dibangun sendiri oleh siswa. Hal ini membuat siswa tidak mudah lupa dan lebih mengerti dengan materi yang sedang dipelajarinya. Materi pelajaran akan tambah berarti jika siswa mempelajari materi pelajaran yang disajikan melalui konteks kehidupan mereka, dan menemukan arti di dalam proses pembelajarannya, sehingga pembelajaran akan menjadi lebih berarti dan menyenangkan.

Saat pelaksanaan pembelajaran, siswa laki-laki cenderung bergurau dan tidak terlalu memikirkan pertanyaan yang terdapat di dalam LKS tersebut. Berbeda dengan siswa perempuan yang lebih memikirkan serta mencoba mencari tahu jawaban dan tidak segan-segan mengacungkan tangan untuk bertanya langsung kepada gurunya.

Pembelajaran fase II (Phairing) seluruh siswa berpasangan saling berbagi dan bekerjasama.Pada fase ini terjadi proses interaksi antara guru dengan siswa dan interaksi siswa dengan siswa. Siswa dikelompokkan secara berpasangan dan saling berdiskusi, sehingga dari hasil diskusi siswa dapat saling bertukar pikiran atau saling membantu. Kegiatan seperti ini cenderung disukai oleh siswa dan membuat siswa aktif dalam belajar. Sesuai dengan teori Lie Think-Pair-Share adalah pembelajaran yang memberi siswa kesempatan untuk bekerja sendiri dan bekerjasama dengan orang lain [6].

Pada fase II (Phairing), terdapat perbedaan yang ditunjukkan oleh siswa laki-laki dan siswa 


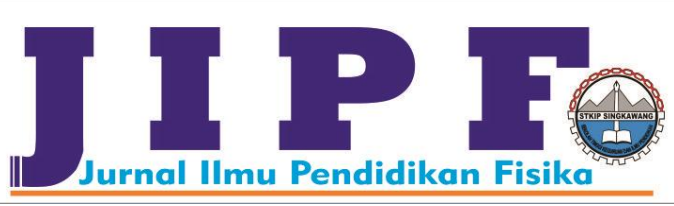

perempuan terjadi pada saat menjawab pertanyaan. Siswa laki-laki masih belum terlihat kerjasamanya, penyelesaian soal dilakukan oleh satu orang siswa yang lebih paham atau mengerti untuk menjawab pertanyaan yang terdapat di dalam LKS tersebut, satu orangnya lagi hanya mencatat hasil akhirnya saja.Berbeda halnya dengan siswa perempuan yang lebih jelas terlihat kerjasamanya dalam menuangkan ide-ide untuk menjawab pertanyaan yang terdapat di dalam LKS tersebut.

Fase berikutnya yaitu fase III (Sharing), guru meminta pasangan-pasangan untuk berbagi dengan keseluruhan kelas yang telah mereka bicarakan. Perbedaan yang ditunjukkan siswa pada fase III (Sharing) siswa laki-laki masih terlihat kesulitan untuk menyampaikan dan menjelaskan kepada teman-temannya mengenai jawaban yang dituliskan di papan tulis, sehingga menimbulkan pertanyaan kembali dari hasil yang telah diperoleh. Siswa perempuan lebih lebih terlihat tenang sehingga apa yang ingin dijelaskan dari jawaban yang dituliskan dipapan tulis itu tersampaikan dengan jelas, sehingga teman-teman yang memperhatikannya mendapat jawaban yang memuaskan. Hal ini sejalan dengan Elliot dalam Putra yang menyatakan bahwa pada aspek kemampuan verbal, perempuan lebih bagus dalam mengerjakan tugas-tugas verbal dan dapat dipertahankan. Laki-laki menunjukkan masalahmasalah bahasa yang banyak dibandingkan perempuan.

Setelah dilakukan pembelajaran menggunakan model kooperatif tipe Think-Pair-Share, siswa diberikan posttest dan diketahui rata-rata hasil belajar siswa perempuan lebih baik dari laki-laki. Hal ini dikarenakan walaupun kecerdasan dan nalar anak laki-laki dan perempuan relatif sama, namun anak perempuan cenderung mengerjakan soal seperti yang diajarkan guru, sedangkan anak lakilaki lebih inovatif dan kreatif dalam meyelesaikan masalah fisika. Itu juga disebabkan karena anak laki-laki jarang hafal apa yang diajarkan gurunya, sehingga mereka mencari cara pemecahannya sendiri. Cara seperti ini memungkinkan untuk siswa laki-laki untuk lebih cenderung mengalami miskonsepsi, terlebih lagi daya ingat siswa laki-laki lebih rendah dibandingkan dengan siswa perempuan.

Adanya perbedaan hasil belajar antara siswa lakilaki dan perempuan sejalan dengan Ariyanti [7], yang menyatakan bahwa rata-rata hasil belajar siswa menggunakan pembelajaran think-pair-share pada materi balok ditinjau dari gender pada siswa kelas VIII SMP Bina Utama Pontianak selama proses pembelajaran tergolong baik bagi siswa lakilaki dan tergolong istimewa bagi siswa perempuan. Ini dapat dilihat dari perhitungan persentase yang diperoleh siswa laki-laki sebesar 75,37\% dan perempuan sebesar $82,74 \%$.

\section{KESIMPULAN DAN SARAN}

\section{A. Simpulan}

Berdasarkan pengolahan data dan pembahasan secara umum dapat disimpulkan bahwa penerapan pembelajaran model kooperatif tipethink-pairshare dalam materi usaha dan isiswa kelas XI IPA SMA Negeri 1 Sungai Ambawang memberikan dampak positif terhadap rata-rata hasil belajar.Adapun kesimpulan secara rinci dari penelitian ini adalah:

a. Rata-rata hasil belajar siswa laki-laki yang diajarkan model pembelajaran kooperatif tipe Think-PairSharedalam materi usaha dan energi siswa kelas XI IPA SMA Negeri 1 Sungai Ambawang mencapai KKM (72) dengan nilai signifikansi lebih besar dari taraf signifikansi 5\% $(0,715>0,05)$.

b. Rata-rata hasil belajar siswa perempuan yang diajarkan model pembelajaran kooperatif tipe ThinkPair-Sharedalam materi usaha dan energi siswa kelas XI IPA SMA Negeri 1 Sungai Ambawang mencapai KKM (72) dengan nilai signifikansi lebih besar dari taraf signifikansi 5\% $(0,185>0,05)$.

c. Terdapat perbedaan antara rata-rata hasil belajar siswa laki-laki dengan rata-rata hasil belajar siswa perempuan yang diajarkan model pembelajaran kooperatif tipe Think-Pair-Share dalam materi usaha dan energi siswa kelas XI IPA SMA Negeri 1 Sungai Ambawang dengan nilai signifikansi lebih besar dari taraf signifikansi 5\% (0,101 > 0,05). Berdasarkan hasil penelitian tersebut bahwa siswa perempuan mendapatkan hasil belajar lebih baik dari pada siswa laki-laki, hal ini terlihat dari rata-rata hasil belajar siswa perempuan dan siswa laki-laki. 
B. Saran

Penelitian ini hanya dilengakapi dengan instrumen dalam bentuk tes, maka sebaiknya pada penelitian berikutnya dilengkapi dengan lembar observasi untuk mengamati aktivitas siswa laki-laki dan perempuan.

\section{DAFTAR PUSTAKA}

[1] Trianto. 2009. Model-model Pembelajaran Inovatif Berorientasi Konstruktivistik. Jakarta: Prestasi Pustaka Publisher.

[2] Martono, Nanang.2010.Perbedaan Gender Dalam Prestasi Akademik Mahasiswa Unsoed. [Online] .Tersedia : http://nanang martono.blog.unsoed.ac.id/files/2010 /09/perbedaan-gender-dalamprestasi-akademik-mahasiswa-unsoed.Pdf. [21 maret 2014].

[3] Soleha, Siti. 2010. Upaya Meningkatkan Aktivitas dan Hasil Belajar Siswa Melalui Model Penbelajaran Think-Pair-Share pada Materi Koloid Kelas XI IPA SMA Negeri 2 Sungai Raya.Pontianak: UNMUH (Tidak Di Publikasikan).

[4] Sugiyono. 2012. Statistik Penelitian Kuantitatif, Kualitatif dan R \& D. Bandung: CV Alfabeta.

[5] Fatima, Fifit. 2012. Pengaruh Model Pembelajaran TPS (Think-Pai Share) terhadap Hasil Belajar Siswa. Jakarta:Salemba.

[6] Lie, Anita.2010.Coopperatif Learning-MempraktikanKooperatif Learning di Ruang-ruang Kelas. Jakarta: PT. Gramedia.

[7] Ariyanti.2013. Penerapan Pendekatan Contexstual Teaching And Learning (CTL) dalam Materi Balok Ditinjau dari Gender pada Siswa Kelas VIII SMP Bina Utama Pontianak. Pontianak: STKIP-PGRI (Tidak di Publikasikan). 